\title{
Reading Fluency and Reading Comprehension Development Characteristics of 1st, 3rd, and 5th Grade Students according to Oral and Silent Reading
}

\author{
Song-Yi Park, Kyunghee Jung \\ Department of Speech and Language Pathology, Graduate School of Rehabilitation and Welfare, Yong-In University, Yongin, Korea
}

Correspondence: Kyunghee Jung, $\mathrm{PhD}$ Department of Speech Language Rehabilitation, Yong-In University, 134 Yongindaehak-ro, Cheoingu, Yongin 17092, Korea

Tel: $+82-31-8020-2864$

Fax: +82-31-8020-3075

E-mail: 1012jkh@hanmail.net

Received: October 11, 2018

Revised: November 12, 2018

Accepted: November 23, 2018

This work is based on a part of the first author's master's thesis from Yong-In University.

\begin{abstract}
Objectives: This study intended to find out the developmental characteristics of reading fluency and reading comprehension according to reading methods (oral reading and silent reading) with elementary school children. Methods: The participants of this study were a total of 48 children in $1 \mathrm{st}, 3 \mathrm{rd}$, and 5 th grade in elementary schools. Four texts were selected as study tools, including two narrative texts and two expository texts. Reading methods were divided into silent and oral reading to study reading fluency, and children were asked to answer to reading comprehension assessment questions. Results: First, as the grade level increased, reading fluency capability also increased. There were significant differences between the 1 st and 5th grade groups and the 3rd and 5th grade groups. According to reading methods, a higher capability in silent reading was exhibited when compared to oral reading. However no interaction effect was shown between groups and reading methods. Second, as the grade level increased, reading comprehension increased, and there were significant differences between 1 st and 3 rd grade and 1 st and 5 th grade. When comparing reading methods, the children showed a higher capability in oral reading than silent reading. But no interaction effect was shown between groups and reading methods. Conclusion: This study found that reading fluency and reading comprehension capability develops as grade level increases, and reading comprehension capability was found to be higher in oral reading than silent reading.
\end{abstract}

Keywords: School-aged children, Reading fluency, Reading comprehension, Oral reading, Silent reading
읽기는 글로부터 의미를 얻는 복잡한 과정으로 성공적인 학교학 습을 수행하기 위한 기초적인 능력 중 하나이다(Kim \& Hwang, 2008; Kwon, 2005). 이를 위해서 다양한 지식과 기술이 요구되는 데, 성공적인 읽기를 위한 지식과 기술은 크게 음운인식, 글자해독, 읽기유창성, 어휘지식, 읽기이해 다섯 가지 요소가 포함된다 $(\mathrm{Na}-$ tional Reading Panel, 2000).

Chall (1983)의 읽기발달 이론에 의하면 초등학교 1-2학년까지는 글자해독의 완성 및 의미이해로의 전이되는 유창성 단계로 이 단계 를 지나 3학년부터는 배우기 위해 읽는 단계로 발달된다고 하였다. 읽기능력에 영향을 미치는 관련변인에 관한 Kim과 Hwang (2008) 의 연구에서는 취학 전이나 초등학교 저학년에서는 기본적인 읽기
기술인 음운인식과 글자해독을 학습하게 되고, 상대적으로 상위 읽기기술인 읽기유창성, 어휘, 읽기이해는 초등학교 전반에 걸쳐서 다루며 중요성이 강조된다고 밝히고 있다.

학령기 아동들은 교과서 내용을 학습하기 위한 주된 방법으로 읽기를 활용하여 다양한 교과의 내용을 학습하게 된다(McCray, Vaughn, \& Neal, 2001). 즉, 학생들은 대부분의 교과학습 시간에 교과서나 문제집과 같은 참고서를 읽어야 하며 읽은 내용에 대하 여 이해하고, 더 나아가 이해한 내용에서 중요한 지식을 습득하도 록 요구되고 있다. 그러므로 읽기는 교과학습에 있어서 필수불가결 한 요소로 간주된다(Armbruster \& Anderson, 1988; Bryant et al., 2000; Kim \& Kang, 2010). 
읽기이해는 자신이 읽은 텍스트의 내용과 의미를 파악하고 이해 하는 능력이다. Wang (1981)은 읽기이해를 인쇄된 자료에서 정보 를 얻는 것으로 정의하고 있다. 그러나 인쇄 자료를 읽을 수 있다 하 여도 자료의 정보를 전달받지 못하면 읽기이해가 이루어진 것으로 볼 수 없다. 능숙한 독자는 개별 단어를 읽고 이해하는 의미의 단위 인 단어 수준의 이해, 문장이 의미하는 바를 이해하는 문장 수준 의 이해, 텍스트를 읽고 이해하는 텍스트 수준의 이해 과정을 거친 다(Vaughn Gross Center for Reading and Language Arts, 2003). 글을 이해하는 과정은 텍스트를 매개로 하여 독자와 필자가 만나 는 지적 과정이다(Kim, 2002). 그런데 글은 목적에 따라 여러 가지 장르가 있으며 각 장르마다 특징적인 구조를 이루고 있는데 이를 텍스트 구조 지식이라고 한다. 글을 효율적으로 이해하기 위해서는 이러한 텍스트 구조에 대한 지식이 중요한 역할을 한다. 즉, 텍스트 구조지식을 활용하여 중요한 정보를 분석하여 의미를 구성해내고, 보다 효율적으로 기억할 수 있게 함으로써 이해를 높일 수 있게 되 는 것이다(Kim, 2017).

하지만 읽기의 궁극적 목적인 읽기이해를 위해서는 독해력의 구 성요소 중 글자해독(decoding)과 이해(comprehension)를 연결하는 역할을 담당하는 읽기유창성이 발달해야 한다(Song, 2009; Woo, Shin, Kim, \& Kim, 2016). 또한 선행연구들에서 읽기유창성 능력의 발달과 글자해독 능력 간의 상관이 있지만, 글자해독 능력의 발달 이 필연적으로 읽기유창성의 발달을 이끄는 것은 아니라는 것이 밝혀지며 읽기유창성의 중요성이 부각되기 시작하였다(National Reading Panel, 2000; Wolf \& Katzir-Cohen, 2001).

읽기유창성의 초기 단계에서 독자는 먼저 글자해독에 주의를 기 울이게 된다. 이후 유창한 단계로 넘어 가면서 글자해독보다는 텍 스트를 이해하기 위해 자신의 인지적인 자원을 사용한다(LaBerge \& Samuels, 1974). 이처럼 읽기유창성은 글자해독이 자동화됨으로 써 성취되는 과정이기 때문에 읽기유창성이 완성되는 단계에 이르 게 되면 읽기 자체에 사용하던 인지적 자원을 읽기이해 과정으로 전이시켜 효율적인 텍스트 이해 처리가 가능해지게 된다(Nathan \& Stanovich, 1991; Song, 2009). 즉, 단어읽기에 집중되어 있던 주의 력이 읽은 단어의 의미를 재구성하는 데 활용됨으로써 효율적 의 미처리를 가능하게 한다는 것이다(Pikulski \& Chard, 2005). Markell과 Deno (1997)의 연구에서는 음독 수행 능력이 향상될 때 읽기이해 과제 수행력도 향상되었다고 보고하였다. Lee와 Kim (2003)의 연 구에서도 읽기유창성 과제에서 높은 수행을 보인 아동일수록 읽기 이해 수행에서도 높은 점수를 받은 것으로 나타나 읽기유창성과 읽기이해 간에는 밀접한 관련이 있으며 학령기 초기 아동의 읽기이 해 능력을 나타내는 주요 지표라고 밝히고 있다. 그러나 읽기유창
성은 오랫동안 글자해독이나 읽기이해에 비하여 상대적으로 관심 을 덜 받아왔으며 글자해독 능력 향상에 중심을 둔 읽기 중재법들 이 주로 연구되어 왔다.

읽기유창성은 텍스트를 정확하게 빨리 읽는 능력, 혹은 힘들이 지 않고 유창하게 소리 내어 읽을 수 있는 능력으로(Clark, 1995), 읽기유창성의 하위 요소는 정확성, 속도, 운율 세 가지로 구성되어 있다(Kuhn \& Stahl, 2003). 이를 세부적으로 살펴보면, 정확성은 단어를 정확하게 인지하거나 해독하는 능력을 말한다. 속도는 연결 된 문맥의 수준, 단일 단어 수준에서의 인지속도를 의미한다. 운율 은 글의 의미 전달을 돕고, 놀람, 의문, 감탄 등의 다양한 감정을 전 달하는 역할을 한다. 이러한 구성 요소들이 원활하게 작동하지 않 는다면 읽는 속도가 느려지고 결국 의미 파악에 어려움을 가지게 된다(Woo et al., 2016).

텍스트를 유창하게 읽는 방식은 음독과 묵독으로 나눌 수 있다. 지금까지 학령기 아동의 읽기유창성의 발달적 특징에 관한 연구는 주로 음독유창성을 중심으로 다루어져 왔다. Kim, Park과 Kim (2010)은 학령기 아동의 읽기유창성의 발달적 차이를 연구한 결과 이야기글의 경우 1 학년과 3 학년, 1 학년과 5 학년 간 차이가 있고, 설 명글의 경우 1 학년과 5 학년, 3 학년과 5 학년 간 차이가 난다고 보고 하였다. Kim과 Park (2010)의 연구에서도 2 학년과 4 학년 간 음독 유창성의 유의미한 차이를 보고하였다. 또한 Kim, Park, Choi와 $\operatorname{Kim}$ (2006)은 초등 2학년과 3학년 사이의 음독유창성이 직선적으 로 발달하나 3 학년 후반기에는 곡선적 추이를 보이며 읽기유창성 발달이 천정점에 도달하는 것으로 보고하였다.

반면 묵독은 눈으로 텍스트를 읽고 이를 음성화하는 과정 없이 뇌에 바로 전달하여 이해하는 단순한 단계를 거치기 때문에 빠르 고 효율적인 읽기가 가능하다(Cho, 2007). Morrison (1968)의 연구 에서는 묵독의 중요성을 강조하고 있으며, 묵독이 매우 유용하다 고 밝히고 있다. 그 이유는 시선의 고정과 시선 되돌리기에서 찾을 수 있다. 음독은 단어를 보고 발음하여야 하므로 시선을 고정시키 는 횟수가 증가하고 긴 시간이 소요된다고 하였다. 반면 묵독은 발 음할 필요가 없으므로 한 곳에 시선이 고정되는 횟수가 적고 길지 않은 시간이 소요되기 때문에 능률적인 읽기방법이라고 하였다. 즉, 음독보다 묵독 시 더 많은 단어를 읽을 수 있게 된다. 초등학교 3 학년 이상에서 고학년으로 진급할수록 묵독유창성을 활용하여 글을 이해하는 활동을 하고 있다(Kim, Cho, \& Koh, 2015). 이처럼 초등학교 3학년 시기까지 낱말재인과 읽기유창성이 발달하여 능 숙한 읽기가 가능해야지만 묵독활동을 통한 성공적인 읽기를 할 수 있다. 실제 학교환경에서는 중학년 이상의 경우 묵독으로 읽고 글을 이해하는 활동 중심으로 실현되고 있고, 대부분의 학업성취 
평가에서 묵독활동을 요구하고 있다. 또한 고학년에 갈수록 텍스 트 분량이 늘어나기 때문에 묵독에 대한 요구는 더 커지게 된다. 그 런데 최근 들어 3-5학년을 대상으로 연구한 결과 3, 4학년과 3, 5학 년 간 묵독유창성의 점수가 유의미하게 차이나며, 묵독유창성이 읽기이해력에 직접적으로 영향을 미치기도 하고 어휘지식을 매개 로 간접적으로 영향을 미치기도 한다는 Kim 등(2015)의 연구가 있 으나지금까지 음독에 비해 묵독에 대한 연구는 미비한 실정이다.

한편 음독과 묵독유창성의 속도와 읽기방식에 따른 읽기이해와 의 관련성을 다룬 몇몇 연구들이 있다. Park (1969)은 음독과 묵독 모두 학년이 올라갈수록 빨라지며 묵독이 음독보다 빠르며, 음독 으로 과제를 수행하였을 때 읽기이해 과제에서 높은 수행이 나타 났다고 보고하였다. 또한 읽기이해부진 학생과 일반학생의 텍스트 이해 능력의 차이를 살펴본 연구에서는 읽기이해부진 학생은 묵독 보다 음독에서 읽기이해 수행이 높게 나타나 음독을 통한 텍스트 이해 의존도가 크다고 밝히고 있다(Jang, 2016). Elgart (1978)와 Swalm (1972) 모두 음독보다 묵독에서 읽기이해 점수가 유의미하 게 높았다는 일관된 결과를 보고하였다.

지금까지의 읽기유창성에 관한 선행연구들은 주로 음독을 중심 으로 이루어져 왔으며 묵독에 대한 관심은 상대적으로 적은 편이 었다. 하지만 초등 중학년 이후 학교 교과학습이 대부분 묵독에 의 존하고 있다는 상황을 고려할 때 묵독유창성의 발달적 특성과 읽 기이해와의 관련성에 대해 다룰 필요가 있다. 따라서 본 연구에서 는 읽기활동 및 읽기이해가 중요한 초등학교 $1,3,5$ 학년을 대상으 로 텍스트 읽기방식(음독 및 묵독)에 따른 읽기유창성 및 읽기이해 능력의 발달 특성을 알아보기 위해 다음과 같은 연구문제를 설정 하였다.

첫째, 읽기방식에 따라학년별 읽기유창성에 능력에차이가 있는가? 둘째, 읽기방식에 따라 학년별 읽기이해 능력에 차이가 있는가?

\section{연구방법}

\section{연구대상}

본 연구는 경기지역에 소재한 초등학생 1학년 17명, 3 학년 16 명, 5 학년 15 명, 총 48 명을 대상으로 하였다. 본 연구는 음독의 유창성 이 정점에 이르는 초등 3 학년기를 전후로 읽기 유창성의 발달 양상 을 보고자 $1,3,5$ 학년을 대상자로 선정하였다. 대상자 선정 기준은 다음과같다.

첫째, 한국어 읽기검사(Korea Language-based Reading Assessment, KOLRA; Pae, Kim, Yoon, \& Jang, 2015)의 하위 항목인 해독 과 읽기이해 검사 결과 $25 \%$ ile 이상에 해당하고, 둘째, 한국 비언어
지능검사 제2판(Korean Comprehensive Test of Nonverbal Intelligence-Second Edition, K-CTONI-2; Park, 2014) 검사 결과 85점 이 상이거나, 셋째, 수용·표현어휘력검사(Receptive and Expressive Vocabulary Test, REVT; Kim, Hong, Kim, Jang, \& Lee, 2009)의 수 용 어휘력 검사 결과 $-1 \mathrm{SD}$ 초과인 학생 중, 넷째, 부모나 교사에 의 해 청각, 시각, 정서.행동상의 문제가 없다고 보고된 학생으로 선정 하였다.

\section{연구도구}

이야기글

본 연구에서는 '한국어 해독해 3 권 이야기와 설명 담화 독해 (Jung, Jin, Kwag, Kim, \& Pae, 2017)'의 글 '짝 바꾸는 날'과 '식물 키 우기'를 저자의 허락을 받아 사용하였다. 연구에 사용된 읽기유창 성 검사지의 예는 Appendix 1에 수록되어 있다. 학년별 읽기지문을 개발하여 실시한 읽기유창성 연구에서 같은 지문을 사용하지 않 았기 때문에 학년별 발달 양상을 살펴보는 데 제한점이 있다고 밝 히고 있다(Kim, Yoo, \& Kim, 2010). 이에 본 연구에서는 동일한 텍 스트를 제시하여 나타나는 학년별 발달을 살펴보기 위해 중학년 수준의 텍스트를 선정하였다. '짝 바꾸는 날'의 문단수는 4 개, 문장 수는 16 개, 평균 어절수는 8.3 개, '식물 키우기'의 문단수는 4 개, 문 장수는 15 개, 평균 어절수는 7.9 개이다. 선정한 이야기 텍스트의 난 이도가 초등학교 중학년 수준에 적합한지 Likert 5 점 척도(매우 그 렇다, 그렇다, 보통이다, 그렇지 않다, 전혀 그렇지 않다) 설문지를 이 용하여 언어치료전공 교수 1 명과 특수교육전공 교수 1 명, 총 2 명을 대상으로 내용타당도를 검사하였다. 텍스트 난이도에 대한 내용타 당도 검사 결과 평균 3.81점으로 나타났다.

\section{설명글}

본 연구에서는 '한국어 해독해 3 권 이야기와 설명 담화 독해 (Jung et al., 2017)'의 글 '황사'와 '호랑이와 토끼'를 저자의 허락을 받아 사용하고, 연구에 맞게 수정 및 보완하였다. 선정된 글의 단어 는 Kim (2003)의 ‘등급별 국어교육용 어휘'를 참고하여 1,2 등급에 해당하는지 검토 후 3,4 등급(예: 서식지)에 해당할 경우 1,2 등급 (예: 사는 곳) 단어로 수정하였다. '황사'의 문단수는 4 개, 문장수는 17 개, 평균 어절수는 7.6개, '호랑이와 토끼'의 문단수 4 개, 문장수 15 개, 평균 어절수 7.9 개이다. 선정한 설명 텍스트의 난이도가 초등 학교 중학년 수준에 적합한지 5점 척도 설문지를 이용하여 언어치 료전공 교수 1 명과 특수교육전공 교수 1 명, 총 2 명을 대상으로 내용 타당도를 검사하였다. 텍스트 난이도 적절성에 대한 내용타당도 검 사 결과 평균 3.7점으로 나타났다. 


\section{읽기이해 검사}

각 이야기글과 설명글에 대한 대상 아동들의 읽기이해 능력을 알아보기 위해 평가문항을 개발하였다. 각 텍스트의 읽기이해 평 가문항은 '한국어 해독해 3 권 이야기와 설명 담화 독해(Jung et al., 2017)'의 읽기이해 질문을 참고하여 연구자가 질문 유형을 수정 및 보완하여 사용하였다.

이야기글과 설명글의 읽기이해 질문 유형은 사실적 이해, 추론 이해를 평가하는 2 가지 유형으로 구성하였다. 질문 문항수는 각각 의 텍스트별로 사실 이해 4 문항, 추론 이해 2 문항 각각 6 문항씩, 총 24 문항으로 구성하였다. 연구에 사용된 읽기이해 검사 문항과 채 점 기준의 예는 Appendix 2에 수록되어 있다. 실험하고자 하는 읽 기이해 문항이 질문 유형으로 적절한지, 정답 채점 기준으로 적합 한지 5 점 척도 설문지를 이용하여 언어치료전공 교수 1 명과 특수교 육전공 교수 1 명, 총 2 명을 대상으로 내용타당도를 검사하였다. 질 문 유형에 대한 내용타당도 검사 결과 평균 3.85점, 채점 기준에 대 한 내용타당도 검사 결과는 평균 3.95점으로 나타났다.

\section{연구절차}

예비 검사

본 연구를 실시하기 전에 연구에 사용할 검사 텍스트가 대상자 에게 적합한지 그리고 학년별 대상자가 본 연구과제를 이해하고 읽 기이해 평가문항을 수행할 수 있는지 검토하기 위하여 본 연구대상 과 조건이 일치하는 초등학교 $1,3,5$ 학년 학생 각각 두 명씩 총 6 명 을 선정하여 예비 검사를 실시하였다. 예비 검사 결과, 여섯 아동 모 두 검사 텍스트를 읽고 이해 과제를 수행하는 데 큰 어려움이 없었 다. 그러나 묵독 읽기유창성 능력을 살펴보기 위해 띄어쓰기 단위 마다 사선(/)을 긋는 방법으로 실시한 결과, 특히 1학년에서 띄어쓰 기에 대한 정확한 개념이 불분명한 것으로 관찰되었다. 따라서 문 장이 끝나는 마침표 단위에서 묵독으로 텍스트를 읽었음을 표시 하는 사선(/)을 긋도록 실시 절차를 수정하였다.

\section{본 검사}

선정검사를 통해 연구목적에 맞는 대상자를 선별한 후 검사를 실시하였다.

본 연구는 빈 강의실, 대상자의 가정 등 소음이 없고 독립된 조용 한 공간에서 개별검사의 형태로 실시하였다. 읽기방식과 텍스트 유 형에 따른 순서효과를 배제하기 위하여 학년별 검사그룹을 A와 B 로 나누어 실시하였다. A그룹은 이야기글을 음독으로 먼저 읽고 나중에 묵독으로 읽었으며, 설명글은 묵독으로 먼저 읽고 나중에 음독으로 읽고 나서 읽기이해 질문에 답하도록 하였다. B그룹은 $\mathrm{A}$
그룹과 반대의 절차로 수행하였다. 읽기이해 과제 수행 시 지문은 보여주지 않았다.

검사자는 대상자에게 음독 텍스트 제공 시 다음과 같이 지시하 였다. "이제부터 선생님이 글을 하나 보여줄 건데, 소리 내서 읽고 글을 다 읽고 나면 선생님이 문제를 보여주고 읽어줄 거야. 그러면 $\bigcirc \bigcirc$ 이가 답이라고 생각하는 것을 말하면 돼. 글은 한 번만 보여주 니까잘 이해하면서 읽어야 해." 이때 검사자는 대상자가 제목을 읽 은 후 본문의 첫 음절을 읽을 때 초시계의 시작 버튼을 누르고 마지 막 음절을 읽을 때 마침 버튼을 눌러 전체 텍스트를 읽는 데 걸린 시간을 측정하였다.

다음으로 묵독 텍스트와 연필을 제공하고 다음과 같이 지시하 였다. "선생님이 글을 하나 더 보여주면서 시작이라고 말할 거야, 그 럼 $\bigcirc \bigcirc$ 이는 소리 내지 않고 눈으로 읽어야 해. 글을 읽으면서 선생 님이 준 연필로 마침표마다 / (사선)를 그으면서 읽으면 돼. 글을 다 읽었으면 손을 들어서 선생님한테 알려줘, 그러면 선생님이 문제를 보여주고 읽어줄 거야. 그러면 $\bigcirc \bigcirc$ 이가 답이라고 생각하는 것을 말하면 돼. 글은 한 번만 보여주니까 잘 이해하면서 읽어야 해." 검 사자는 대상 아동이 묵독으로 읽는 것을 확인하기 위해 텍스트를 읽을 때 마침표를 중심으로 / (사선)를 그어가며 읽도록 하고, "시 작"이라고 신호를 주며 초시계의 시작 버튼을 누른다. 대상아동이 마지막 마침표에 / (사선)를 긋고 손을 들어 다 읽었음을 알릴 때 초 시계의 마침 버튼을 눌러 전체 텍스트를 읽는 데 걸린 시간을 측정 하였다. 검사자는 대상 아동의 대답을 듣고 검사지에 기록 및 녹음 기에 녹음하여 검사 종료 후 녹음자료와 검사 기록지를 비교하여 대상자의 답안을 정확하게 기록하였다.

\section{자료분석}

채점 기준

읽기유창성 검사

본 연구에서 읽기유창성 측정은 속도를 중심으로 하였다. 이는 음독과 묵독의 유창성을 비교하는 데 목적이 있는데 묵독의 경우 정확도나운율을 측정하여 수량화하는 데 제한점이 있기 때문이다. 또한 읽기유창성의 학년별 차이를 보여주는 것이 정확도보다는 속 도가 중요한 역할을 한다고 한 Kim, Park 등(2010)의 연구를 참고하 였다.

음독유창성 검사의 채점은 대상 아동이 제목을 읽는 순간부터 전체 텍스트를 모두 읽는 데 걸리는 시간을 측정하였다. 이 후 전체 읽은 음절수를 전체 텍스트를 읽는 데 걸린 시간으로 나눈 뒤 10 을 곱하여 10 초당 정확하게 읽은 음절수를 산출하였다. 


$$
\frac{\text { 전체 읽은 음절수 }}{\text { 전체 텍스트를 읽는 데 걸린 시간(초) }} \times 10
$$

묵독유창성 검사의 채점은 검사자가 대상 아동에게 텍스트를 제시하고 “시작”을 말한 순간부터 대상 아동이 마지막 마침표에 / (사선) 표시를 하여 전체 텍스트 읽기를 마치는 데까지 소요되는 시간을 측정하였다. 이 후 전체 읽은 음절수를 전체 텍스트를 읽는 데 걸린 시간으로 나눈 뒤 10 을 곱하여 10 초당 읽은 음절수를 산출 하였다.

$$
\frac{\text { 전체 읽은 음절수 }}{\text { 전체 텍스트를 읽는 데 걸린 시간(초) }} \times 10
$$

읽기이해검사

읽기이해 평가문항의 경우 각 텍스트 읽기를 마친 후 읽기이해 검사지를 제시하여 텍스트마다 6문항씩, 총 24 문항에 응답하도록 하였다. 이때 검사자가 검사문항을 읽어주고 대상자는 검사문항을 눈으로 확인하며 구두로 대답하도록 하였다. 대답하기 원치 않는 대상자는 검사지에 답을 쓰도록 하였다.

응답에 대한 시간 제한은 두지 않았다. 각 문항은 채점 기준에 따 라 적절한 답은 1 점, 잘못된 답이나 완전하지 못한 답, 무응답의 경 우 0 점으로 채점하여 점수를 계산하였다. 채점 기준은 Appendix 2 에 제시하였다.

\section{통계처리}

본 연구에서 수집된 자료를 SPSS 21.0 Windows용 프로그램을 사용하여 다음과 같이 분석하였다. 첫째, 읽기방식에 따라 학년별 읽기유창성 능력에 차이가 있는지 알아보기 위해 이원분산분석 (two-way ANOVA)을 실시하였고, 둘째, 읽기방식에 따라 학년별

Table 1. Descriptive statistics of reading fluency according to reading method

\begin{tabular}{lrr}
\hline & Reading method & Reading fluency \\
\hline 1st grade & $O R(N=17)$ & $77.74(21.163)$ \\
& $S R(N=17)$ & $101.16(37.462)$ \\
3rd grade & Total $(N=34)$ & $89.45(32.231)$ \\
& $O R(N=16)$ & $84.91(13.446)$ \\
5th grade & $S R(N=16)$ & $123.58(54.679)$ \\
& Total $(N=32)$ & $104.25(43.817)$ \\
& $O R(N=15)$ & $103.51(14.205)$ \\
& $S R(N=15)$ & $159.94(44.140)$ \\
& Total $(N=30)$ & $131.73(43.144)$ \\
\hline
\end{tabular}

Values are presented as mean (SD).

$\mathrm{OR}=$ oral reading; $\mathrm{SR}=$ silent reading.
읽기이해 능력에 차이가 있는지 알아보기 위해 이원분산분석(twoway ANOVA)을 실시하였다.

\section{신뢰도}

신뢰도는 학년별로 읽기유창성 및 읽기이해 질문 자료의 약 $20 \%$ 에 해당하는 학년별 3 명씩, 총 9 명의 자료에 대하여 연구자와 제 2 채 점자의 채점 결과 간의 일치율을 구하였다. 제 2 평가자는 본 연구의 목적과 내용을 충분히 숙지한 언어치료 석사과정 대학원생 1 명이 다. 올바른 채점을 위하여 채점에 관한 훈련을 진행한 후, 두 채점자 는 독립적으로 채점하였다. 그 결과 연구자와 채점자 간 읽기유창 성 채점점수의 신뢰도는 $100 \%$, 읽기이해 채점점수의 신뢰도는 90\%로 산출되었다.

\section{연구결과}

\section{읽기방식에 따른 학년별 읽기유창성 능력}

읽기방식에 따른 학년별 읽기유창성 수행력에 대한 기술통계 결 과는 Table 1 과 같다.

Table 1에서 나타난 바와 같이 읽기방식에 따른 학년별 읽기유창 성의 차이를 살펴보면 텍스트를 음독하였을 때, 1학년은 평균 77.74 ( $\mathrm{SD}=21.163), 3$ 학년은 평균 $84.91(\mathrm{SD}=13.446), 5$ 학년은 평균 103.51 $(\mathrm{SD}=14.205)$ 이었다. 텍스트를 묵독하였을 때, 1학년은 평균 101.16 ( $\mathrm{SD}=37.462)$, 3학년은 평균 123.58 ( $\mathrm{SD}=54.679), 5$ 학년은 평균 $159.94(\mathrm{SD}=44.140)$ 이었다. 학년이 증가함에 따라 음독 및 묵독유 창성 수행력이 증가하였으며, 음독보다 묵독에서 더 높은 수행력을 보였다.

이러한 차이의 통계적 유의미성을 알아보기 위해 반복측정 이원 분산분석을 실시한 결과 학년 $\left(F_{(2,90)}=12.171, p<.05\right)$ 과 읽기방식 $\left(F_{(1,90)}=31.338 p<.05\right)$ 에 따라 통계적으로 유의한 차이가 있는 것 으로 나타났으나 읽기방식과 집단 간의 유의한 상호작용효과는 유

Table 2. One-way ANOVA of reading fluency according to reading method $(\mathrm{N}=102)$

\begin{tabular}{llrrrcc}
\hline & & \multicolumn{1}{c}{ SS } & df & \multicolumn{1}{c}{ MS } & $F$ & Scheffe \\
\hline OR & Between & $5,547.677$ & 2 & $2,773.838$ & $9.826^{*}$ & $1<5^{*}, 3<5^{*}$ \\
& Within & $12,703.897$ & 45 & 282.309 & & \\
& Total & $18,251.574$ & 47 & & & \\
SR & Between & $27,809.718$ & 2 & $13,904.859$ & $6.616^{*}$ & $1<5^{*}$ \\
& Within & $94,578.874$ & 45 & $2,101.753$ & & \\
& Total & $122,388.592$ & 47 & & & \\
\hline
\end{tabular}

$\mathrm{OR}=$ oral reading; $\mathrm{SR}=$ silent reading. ${ }^{*} p<.05$. 
Table 3. Descriptive statistics of reading comprehension according to reading method

\begin{tabular}{lrc}
\hline & Reading method & Reading comprehension \\
\hline 1st grade & $O R(N=17)$ & $6.64(1.54)$ \\
& $S R(N=17)$ & $6.05(1.43)$ \\
3rd grade & Total $(N=34)$ & $6.35(1.50)$ \\
& $O R(N=16)$ & $8.68(1.74)$ \\
5th grade & $S R(N=16)$ & $8.00(1.71)$ \\
& Total $(N=32)$ & $8.34(1.73)$ \\
& $O R(N=15)$ & $9.60(.91)$ \\
& $S R(N=15)$ & $8.60(1.06)$ \\
& Total $(N=30)$ & $9.10(1.09)$ \\
\hline
\end{tabular}

Values are presented as mean (SD).

$\mathrm{OR}=$ oral reading; $\mathrm{SR}=$ silent reading .

의하지 않았다 $\left(F_{(2,90)}=1.821, p>.05\right)$. 집단 간 차이에 대한 사후검 정 결과 1 학년과 5 학년, 3 학년과 5 학년 집단 사이에서 나타났다.

또한 각각의 읽기방식에 따라 집단 간 차이가 유의미한지 알아보 기 위해 일원분산분석을 실시한 결과 음독과 묵독 모두 통계적으 로 유의미한차이가 났다.

Table 2에서 보는 바와 같이 음독 $\left(F_{(2,45)}=9.826, p<.05\right)$ 및 묵독 $\left(F_{(2,45)}=6.616, p<.05\right)$ 에서 집단 간 통계적으로 유의한 차이가 있는 것으로 나타났다. 각각의 읽기방식에 따른 읽기유창성 수행 능력의 차이가 어느 학년에서 나타났는지 알아보기 위해 Scheffe 사후검정 을 실시한 결과 음독에서 집단 간 읽기유창성 수행력의 유의미한 차이는 1 학년과 5 학년, 3 학년과 5 학년 집단 사이에서 있었고, 묵독 에서는 1 학년과 5 학년 집단 사이에서 읽기유창성 수행력의 유의미 한차이가 나타났다.

\section{읽기방식에 따른 학년별 읽기이해 능력}

읽기방식에 따른 학년별 읽기이해 수행력에 대한 기술통계 결과 는 Table 3과 같다.

Table 3에서 나타난 바와 같이 읽기방식에 따른 학년별 읽기이해 수행력의 차이를 살펴보면 텍스트를 음독하였을 때, 학년이 증가 함에 따라 수행력이 증가하였으며, 묵독보다 음독에서 더 높은 수 행력을 보였다.

이러한 차이의 통계적 유의미성을 알아보기 위해 반복측정 이원 분산분석을 실시한 결과 읽기이해 능력은 학년 $\left(F_{(2,45)}=31.402, p<\right.$ $.05)$ 과 읽기방식 $\left(F_{(2,45)}=6.613 p<.05\right)$ 에 따라 통계적으로 유의한 차이가 있는 것으로 나타났으나 읽기방식과 집단 간의 유의한 상호 작용효과는 통계적으로 유의하지 않았다 $\left(F_{(2,45)}=.173, p>.05\right)$. 집 단 간 주효과가 어떤 집단에서 차이를 나타났는지 알아보기 위하 여 Sheffe 사후검정을 실시한 결과, 읽기방식에 따른 읽기이해 수행
Table 4. One-way ANOVA of reading comprehension according to reading method ( $\mathrm{N}=102)$

\begin{tabular}{llrrrcc}
\hline & & SS & df & MS & \multicolumn{1}{c}{$F$} & Scheffe \\
\hline OR & Between & 74.08 & 2 & 37.04 & $17.56^{*}$ & $1<3^{*}, 1<5^{*}$ \\
& Within & 94.92 & 45 & 2.11 & & \\
& Total & 169.00 & 47 & & & \\
SR & Between & 57.46 & 2 & 28.73 & $13.97^{*}$ & $1<3^{*}$ \\
& Within & 92.54 & 45 & 2.06 & & $1<5^{*}$ \\
& Total & 150.00 & 47 & & & \\
\hline
\end{tabular}

$\mathrm{OR}=$ oral reading; $\mathrm{SR}=$ silent reading.

${ }^{*} p<.05$.

력의 집단 간 유의미한 차이는 1 학년과 3 학년, 1 학년과 5 학년 집단 사이에서 나타났다(Table 4).

또한 각각의 읽기방식에 따라 집단 간차이가 유의미한지 알아보 기 위해 일원분산분석을 실시한 결과 음독과 묵독 모두 통계적으 로 유의미한 차이가 났다. 사후검정 결과 음독과 묵독 모두 1학년 과 3 학년, 1 학년과 5 학년 집단 사이에서 유의미한 차이가 나타났다.

\section{논의 및 결론}

본 연구에서는 초등학교 $1,3,5$ 학년 아동을 대상으로 읽기방식 (음독과 묵독)에 따른 읽기유창성 능력과 읽기이해 능력에 차이가 있는지 알아보았다. 연구 결과에 대한 논의는 다음과 같다.

첫째, 읽기방식에 따라 학년별 읽기유창성 능력의 차이를 살펴본 결과, 학년과 읽기방식에 따라 유의한 차이가 있는 것으로 나타났다.

먼저, 전체적으로 학년에 따라 읽기유창성이 증가하는 경향을 보 이나 1 학년과 5 학년, 3 학년과 5 학년 집단에서 유의한 차이가 나타 났고, 1학년과 3학년에서는 유의한 차이가 나타나지 않았다. 이는 음독과 묵독을 포함한 전체 점수와 음독 점수에서는 같은 결과로 나타났지만 묵독만 볼 때는 1 학년과 5 학년에서만 차이가 나타났다. 이는 음독의 경우 저학년에서 중학년 간은 완만히 발달하다 중학 년에서 고학년에 급격한 발달을 보인다는 것으로 해석해 볼 수 있 다.Woo 등(2016)의 연구에서 학년이 증가함에 따라 읽기유창성 수 행력이 높아지며, 저학년보다 고학년에서 읽기가 유창하다고 보고 하였는데 이는 본 연구와 일치하는 결과이다. 본 연구와 대상자는 다르지만 Park (1969)의 연구에서도 일반아동과 읽기부진아동 모 두 음독과 묵독 두 가지 읽기방식 모두 학년이 높아짐에 따라 읽기 유창성 수행력이 증가하였다고 보고한 결과와도 유사하다. 학령기 아동들은 학년이 올라갈수록 읽어야 할 텍스트의 양이 많아지고 더 빠른 처리를 요구받게 될 뿐만 아니라 일견 단어나 배경지식 등 의 증가가 읽기속도에 영향을 미치게 된 것으로 해석해 볼 수 있다. 
하지만 Kim, Park과 Kim (2010)의 연구에서는 1,3,5학년에 읽 기유창성이 증가하기는 하나 이야기글은 저학년에서 중학년이 설 명글은 중학년과 고학년에서 급격한 발달을 보인다고 하여 다소 차 이가 있다. 이는 Kim, Park과 Kim (2010)의 연구에서는 이야기글 과 설명글을 따로 살펴 보았으나 본 연구는 두 유형의 텍스트를 함 께 과제로 다루었고 전체 수행력에 묵독 수행력도 포함되어 있기 때문이라고 해석해 볼수 있다.

다음으로, 읽기방식에 따라서는 텍스트를 음독할 때보다 묵독 하였을 때 읽기유창성 수행능력이 유의미하게 높았다. 본 연구와 대상자는 다르지만 Park (1969)은 읽기방식에 따른 읽기이해 능력 에서 일반아동과 읽기부진 아동 모두 음독으로 읽을 때보다 묵독 으로 읽을 때 더 수행력이 빠르다고 보고하였는데 이는 본 연구 결 과와 유사하다. 본 연구 결과, 묵독에서는 1학년과 5 학년 집단에서 유의한 차이가 있었고, 1 학년과 3 학년, 3 학년과 5 학년 집단에서는 유의한 차이가 나타나지 않았다. 국내에서는 대부분 음독유창성 능력을 중심으로 연구가 이루어지고 있으며, 묵독유창성 능력만을 살펴본 학년별 발달 연구가 많지 않으므로 추후 후속 연구가 필요 한 것으로 보인다.

둘째, 읽기방식에 따라 학년별 읽기이해 능력의 차이를 살펴본 결 과, 학년과 읽기방식에 따라 유의한차이가 있는 것으로 나타났다.

먼저, 전체적으로 학년이 올라갈수록 읽기이해 수행력이 높아지 는 경향을 보이는 것으로 나타났으며, 1학년과 3학년, 1 학년과 5 학 년 사이에서 학년 간 차이가 통계적으로 유의미했다. 이러한 결과 는 저학년에 비해 고학년의 읽기이해 수행력이 유의미하게 높은 것 으로 볼 수 있다. 이는 초등학교 1,3,5학년을 대상으로 한 읽기이해 능력을 비교한 Kim, Kim과 Sung (2013)의 연구에서 학년에 따른 읽기이해 능력에 유의한 차이가 나타났다는 보고를 지지해주는 결 과이다. 또한 초등학교 2-5학년 아동의 읽기이해 능력 발달을 살펴 본 Hwang, Kim과 Lee (2007)의 연구에서도 학년 간 읽기이해 능력 이 유의한 차이가 있는 것으로 밝히고 있으며, 학령기 아동들의 읽 기이해 능력은 지속적인 향상을 보인다는 보고와 일치하는 결과이 다. 이러한 결과는 학년이 높아짐에 따라 글자 해독이 자동화되어 텍스트의 의미를 구성하는 데 자원을 할애할 수 있게 되고, 어휘지 식이 늘어날 뿐만 아니라 읽기경험에 노출된 양이 증가함으로써 배 경지식을 텍스트 이해를 위해 효율적으로 활성화하는 등 읽기를 위한 언어-인지적 자원이 늘어나기 때문이라고 해석된다.

다음으로, 읽기방식에 따라서는 음독 및 묵독에서 1학년과 3학 년, 1 학년과 5 학년 집단에서 유의한 차이가 있었고, 3 학년과 5 학년 집단에서 유의한 차이가 나타나지 않았다. 또한 텍스트를 묵독할 때보다음독할 경우 읽기이해 수행능력이 유의하게 높은 것으로 나
타났다. 이는 고학년이라도 묵독보다는 음독이 텍스트를 읽고 이 해하는 데 더 효과적이라는 No (2010)의 연구를 지지해주는 결과 이다. 또한 Cho (2007)의 연구에서 밝히고 있는 것과 같이 묵독보 다 음독이 아동의 학습능력에 더 많은 영향을 미친다고 한 연구결 과와 유사하다. 이는 초등 3학년을 대상으로 연구한 Elgart (1978) 와초등학생뿐 아니라 중학생까지를 대상으로 한 Hale 등(2007) 등 의 해외 연구결과와도 일치하는 결과이다. 이는 음독의 경우 텍스 트에 있는 단어를 시각으로 인지하면서 동시에 청각적으로 변환시 켜야 하는 다감각적 의미처리를 하지만 묵독의 경우 시각에만 의존 해 의미처리가 이루어지기 때문에 음독이 좀 더 효율적으로 단어 의 의미에 집중할 수 있기 때문이라고 해석해 볼 수 있다(Elgart, 1978).

본 연구와 대상자는 다르지만, Jang (2016)의 연구에서도 읽기이 해부진 학생은 음독에서 읽기이해 수행력이 높은 것으로 나타났 다. 이러한 결과는 장애 유무에 상관없이 텍스트를 음독할 경우 읽 기이해 수행능력이 더 좋은 것으로 해석해 볼 수 있다. 그러나 학년 에 따라 읽기이해력에 유의한차이가 나타나지 않았다는 Kim (2011) 의 연구결과와 다른데, 이는 본 연구와 실험에 사용된 글의 난이도 및 과제 유형의 차이로 인한 것으로 보인다. Kim (2011)의 연구에서 는 길이가 짧은 지문을 여러 개 제시하였고, 모든 평가문항을 객관 식으로 구성하여 제시하였다. 국내 성인을 대상으로 한 음독 및 묵 독 연구는 없지만, 대학과 대학원에 재학중인 고급 한국어 학습자 를 대상으로 한 Wang과 Won (2017)의 연구에서는 난이도가 낮은 텍스트의 경우 묵독과 음독의 이해능력에 유의한 차이가 나타나 지 않았지만, 난이도가 높은 텍스트의 경우 음독이 이해에 더 높은 영향이 있음을 밝히고 있다. 이러한 결과는 성인에서도 텍스트에 따라음독이 효율적일 수 있음을 알수 있다.

본 연구의 결과로 보아, 학년이 올라감에 따라 음독 및 묵독유창 성 능력이 증가하고 읽기이해 능력에 있어서는 묵독보다 음독에서 수행능력이 유의미하게 높았음을 알 수 있었다. 따라서 추후 학령 기 아동을 대상으로 읽기지도를 할 경우 초등학교 저학년뿐만 아 니라 고학년에서도 읽기이해 지도 시 음독에 대한 고려가 필요하 다. 더불어 본 연구에서는 읽기유창성을 속도의 측면에서만 분석하 고 정확도를 반영하지 못하였는데 이는 묵독의 정확도를 측정하는 데 제한점이 있어서였다. 묵독의 정확도를 측정하기 위한 방법론을 보완하여 속도뿐 아니라 정확도까지 함께 보지 못한 점이 있다. 추 후 이러한 점을 보완한 후속 연구로 음독뿐 아니라 묵독 유창성에 대한 총체적 해석이 가능해지기를 기대한다.

본 연구에서는 글의 유형에 따른 차이점은 살펴보지 못하여 이 에 따른 유창성 능력과 이해 능력을 예측하는 데 한계점이 있다. 또 
Song-Yi Park, et al. • Reading Fluency and Reading Comprehension according Reading Methods

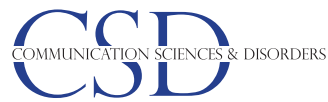

한 전학년을 대상으로 하지 못하고 $1,3,5$ 학년을 대상으로 하였으 며 대상자의 수가 적어 일반화해서 해석하는 데는 제한점이 있다.

이후 후속 연구에서는 전학년을 대상으로 발달적 추이를 살펴보 는 연구가 필요할 것이다. 또한 실제 국어교과서에는 이야기글과 설 명글이 차지하는 비중이 높으므로 후속 연구에서는 이야기글과 설 명글을 포함한 다양한 종류의 글에서 읽기방식을 달리하였을 때 읽기유창성 능력과 읽기이해 능력의 차이를 살펴볼 필요가 있을 것 으로 보인다.

\section{REFERENCES}

Armbruster, B. B., \& Anderson, T. H. (1988). On selecting "considerate" content area textbooks. Remedial and Special Education, 9, 47-52.

Bryant, D. P., Vaughn, S., Linan-Thompson, S., Ugel, N., Hamff, A., \& Hougen, M. (2000). Reading outcomes for students with and without reading disabilities in general education middle-school content area classes. Learning Disability Quarterly, 23, 238-252.

Chall, J. S. (1983). Stages of reading development. New York, NY: McGrawHill.

Cho, M. (2007). A study on grade differences in the effect of reading methods on the self-directed learning ability of the children. Journal of the Korean Library and Information Science Society, 41, 251-271.

Clark, C. H. (1995). Teaching students about reading: a fluency example. Reading Horizons, 35, 250-266.

Elgart, D. B. (1978). Oral reading, silent reading, and listening comprehension: a comparative study. Journal of Reading Behavior, 10, 203-207.

Hale, A. D., Skinner, C. H., Williams, J., Hawkins, R., Neddenriep, C. E., \& Dizer, J. (2007). Comparing comprehension following silent and aloud reading across elementary and secondary students: implication for curriculum-based measurement. The Behavior Analyst Today, 8, 9-23.

Hwang, J. A., Kim, Y. T., \& Lee, J. Y. (2007). Reading comprehension ability in school-aged children. Korean Journal of Communication \& Disorders, 12, 412-428.

Jang, H. S. (2016). Reading comprehension of narrative text in poor comprehenders by reading methods (Master's thesis). Dankook University, Yongin, Korea.

Jung, K., Jin, Y., Kwag, K., Kim, M., \& Pae, S. (2017). Korean Literacy 3: reading comprehension of narrative and expository discourses. Seoul: Hakjisa.

Kim, A. H., \& Hwang, M. (2008). Prediction of reading skills in upper elementary students. Korean Journal of Communication \& Disorders, 13, 1-25.
Kim, A. H., \& Park, S. H. (2010). Reading fluency of elementary students with and without reading disabilities: reading developmental patterns and errors. The Journal of Special Education: Theory and Practice, 11, 323-345.

Kim, A. H., Kim, U. J., \& Sung, S. Y. (2013). A study of the reading comprehension characteristics of 1st, 3rd, and 5th grade students: focusing on higher-order reading comprehension processes. The Journal of Elementary Education, 26, 21-42.

Kim, A. H., Park, S. H., \& Kim, J. H. (2010). Reading fluency of elementary students in Korea: reading developmental patterns and error patterns. Korean Journal of Communication \& Disorders, 15, 43-55.

Kim, A. H., Yoo, H. S., \& Kim, U. J. (2010). Prediction of word recognition, reading fluency and reading comprehension: a longitudinal study of 5-yearold and 6-year old children. The Journal of Elementary Education, 23, 427453.

Kim, D., Cho, Y., \& Koh, H. (2015). Relationships between silent word reading and reading comprehension. Journal of Education Psychology, 28, 169183.

Kim, D. I., Park, C. S., Choi, J. K., \& Kim, I. S. (2006). Reading fluency development of elementary school students in regular and special class. Korean Journal of Educational Psychology, 20, 425-442.

Kim, H. (2011). Comparison of reading fluency and reading comprehension between students with normal and poor reading (Master's thesis). Yong-In University, Yongin, Korea.

Kim, K. (2003). Vocabularies for different levels of Korean education. Seoul: Pagijung.

Kim, M., \& Kang, O. (2010). The effect of collaborative strategic reading and reading fluency and reading comprehension or low-achieving students in reading. The Korean Journal of Learning Disabilities, 7, 97-117.

Kim, S. (2002). A study on instruction of narrative text using a story structure: focused on third grades in elementary school (Master's thesis). Seoul National University of Education, Seoul, Korea.

Kim, Y. S. (2017). Reading \& writing education. Seoul: Hakjisa.

Kim, Y. T., Hong, G. H., Kim, K. H., Jang, H. S., \& Lee, J. Y. (2009). Receptive \& expressive vocabulary test (REVT). Seoul: Seoul Community Rehabilitation Center.

Kuhn, M. R., \& Stahl, S. A. (2003). Fluency: a review of developmental and remedial practices. Journal of Educational Psychology, 95, 3-21.

Kwon, J. S. (2005). The effects on reading fluency and reading comprehension to present pre-experience of life related to reading subject for reading disabilities. Korean Journal of Special Education, 40, 313-331. 
LaBerge, D., \& Samuels, S. J. (1974). Toward a theory of automatic information processing in reading. Cognitive Psychology, 6, 293-323.

Lee, I. H., \& Kim, D. I. (2003). The relationship between reading fluency and reading comprehension in primary grades. Journal of Education Psycholo$g y, 17,1-24$.

Markell, M. A., \& Deno, S. L. (1997). Effects of increasing oral reading: generalization across reading tasks. The Journal of Special Education, 31, 233250.

McCray, A. D., Vaughn, S., \& Neal, L. V. I. (2001). Not all students learn to read by third grade: middle school students speak out about their reading disabilities. The Journal of Special Education, 35, 17-30.

Morrison, I. E. (1968). Teaching reading in the elementary school. New York, NY: Ronald Press.

Nathan, R. G., \& Stanovich, K. E. (1991). The causes and consequences of differences in reading fluency. Theory into Practice, 30, 176-184.

National Reading Panel. (2000). Teaching children to read: an evidence-based assessment of the scientific research literature on reading and its implications for reading instruction. Washington, DC: National Institute of Child Health and Human Development.

No, E. S. (2010). The effects of reading methods on reading comprehension in elementary school class (Master's thesis). Kongju University, Gongju, Korea.

Pae, S., Kim, M., Yoon, H. J., \& Jang, S. (2015). Korean language-based reading assessment. Seoul: Hakjisa.

Park, H. (2014). Korean version of Comprehensive Test of Nonverbal Intelligence Second Edition (K-CTONI-2). Seoul: Mindpress.
Park, S. (1969). Study on the effects of oral and silent reading on the reading abilities. The Academy for Korean Language Education, 13, 14-46.

Pikulski, J. J., \& Chard, D. J. (2005). Fluency: bridge between decoding and reading comprehension. The Reading Teacher, 58, 510-519.

Song, Y. (2009). How to improve reading fluency for multi-cultural Korean learners. Journal of Elementary Korean Education, 41, 36-57.

Swalm, J. E. (1972). A comparison of oral reading, silent reading and listening comprehension. Education, 92, 111-115.

Vaughn Gross Center for Reading and Language Arts. (2003). Effective instruction for secondary struggling readers: research-based practices. Austin, TX: Author.

Wang, E. M., \& Won, M. J. (2017). A study on the effects of Korean reading methods on advanced learners' comprehension and expression-by comparing oral reading and silent reading. Korean Language and Literature in International Context, 72, 205-228.

Wang, M, Y. (1981). A study on improvement of reading teaching methodproblems of loud and silent reading. The Education of Korean Language, 138, 185-196.

Wolf, M., \& Katzir-Cohen, T. (2001). Reading fluency and its intervention. Scientific Studies of Reading, 5, 211-239.

Woo, J., Shin, H., Kim, J., \& Kim, M. (2016). A comparative study on the characteristics and relations of RAN, reading fluency and reading comprehension of students with reading disabilities and general students. Journal of Special Education \& Rehabilitation Science, 55, 163-183. 
Appendix 1. 읽기유창성 및 읽기이해 이야기 텍스트의 예

$$
\text { 짝 바꾸는 날 }
$$

내일은 한 달에 한 번 짝 바꾸는 날이에요.

선생님께서는 어떻게 바꿀지 의견을 내보라고 하셨어요.

나는 손을 높이 들었어요.

"아침에 먼저 온 순서대로 자리에 앉는 것이 좋겠어요."라고 이야기하였어요.

아이들과 선생님 모두 좋아하였고 내 의견을 따르기로 하였어요.

다음날 나는 늦게 일어나서 허겁지겁 학교에 갔어요.

자리는 꽉 차 있었고 키가 크고 목소리가 큰 경미의 옆만 비어 있었어요.

나는 경미가 무서워서 가인이에게 살짝 가서 짝을 바꾸자고 했어요.

하지만 가인이가 싫다고 해서 나는 어쩔 수 없이 경미 옆에 앉을 수밖에 없었어요.

나는 가방을 열어 필통을 꺼내려고 하는데 필통이 보이지 않았어요.

내가 허둥지둥거리자 경미는 연필을 빌려주었어요.

나는 말없이 경미에게 연필을 받았어요.

경미는 나에게 연필을 주며 “우리 한 달 동안 재밌게 지내자”라고 반갑게 말을 걸었어요.

경미는 더 이상 무섭지 않았어요.

나는 연필을 빌려줘서 고맙다고 하며 가방에 있는 초콜릿을 건네주었어요.

우리는 둘도 없는 친구가 되었고 나는 계속 경미와 함께 짝이 되고 싶었어요.

Appendix 2. 읽기이해 검사 문항 및 채점 기준의 예

\begin{tabular}{|c|c|c|c|}
\hline 문항 유형 & 검사 문항 & 0점 & 1점 \\
\hline \multirow{4}{*}{$\begin{array}{l}\text { 사실적 } \\
\text { 이해 }\end{array}$} & 1. 내일은 어떤 날인가요? & $\begin{array}{l}\text { - 질문과 관련 없는 답을 언급(예: 학교 가요.) } \\
\text { - 모른다 또는 무응답. }\end{array}$ & - 짝 바꾸는 날 \\
\hline & 2. 나는 짝 바꾸는 날에 어떤 의견을 냈나요? & $\begin{array}{l}\text { - 질문과 관련 없는 답을 언급(예: 빨리 와요.) } \\
\text { - 모른다 또는 무응답. }\end{array}$ & - 먼저 온 순서대로 자리에 앉는다. \\
\hline & $\begin{array}{l}\text { 3. 다음 날 나는 왜 경미의 옆자리에 앉게 되었 } \\
\text { 나요? }\end{array}$ & $\begin{array}{l}\text { - 질문과 관련 없는 답을 언급 } \\
\text { - 모른다 또는 무응답. }\end{array}$ & $\begin{array}{l}\text { - 아침에 늦게 일어나서 학교에 갔더니 } \\
\text { 경미 옆만 비어있었다. }\end{array}$ \\
\hline & 4. 나는 왜 경미가 무서웠나요? & $\begin{array}{l}\text { - 질문과 관련 없는 답을 언급 } \\
\text { - 모른다 또는 무응답. }\end{array}$ & - 키와 목소리가 커서 무서운 줄 알았다. \\
\hline 문항 유형 & 검사 문항 & 0점 & 1점 \\
\hline \multirow[t]{2}{*}{ 추론 이해 } & $\begin{array}{l}\text { 5. 연필을 가지고 오지 않았을 때 나는 기분이 } \\
\text { 어땠을까요? }\end{array}$ & $\begin{array}{l}\text { - 질문과 관련 없는 답을 언급(예: 엄마한테 } \\
\text { 전화해요.) } \\
\text { - 모른다 또는 무응답. }\end{array}$ & - 당황스러운 기분과 관련된 내용이 포함. \\
\hline & $\begin{array}{l}\text { 6. 다음에도 경미와 짝이 되려면 어떻게 해야 } \\
\text { 할까요? }\end{array}$ & $\begin{array}{l}\text { - 질문과 관련 없는 답을 언급(예: 같이 앉아요.) } \\
\text { - 모른다 또는 무응답. }\end{array}$ & $\begin{array}{l}\text { - 학교에 일찍 와서 경미 옆자리에 앉는다 } \\
\text { 는 내용이 포함. }\end{array}$ \\
\hline
\end{tabular}




\section{국문초록}

\section{음독과 묵독에 따른 학령기 아동의 읽기유창성과 읽기이해 발달 특성 \\ 박송이(학생, 제1저자) · 정경희(교수, 교신저자) \\ 용인대학교 재활복지대학원 언어치료학과}

배경 및 목적: 본 연구는 학령기 아동을 대상으로 읽기방식(음독 및 묵독)에 따른 읽기유창성 능력과 읽기이해 능력의 발달적 특성을 알아보고자 하였다. 방법: 연구대상은 경기 지역 내 초등학교에 재학 중인 1학년 17명, 3 학년 16 명, 5 학년 15 명으로 총 48 명이었다. 연구 도구는 ‘한국어 해독해 3 권 이야기와 설명 담화 독해'에서 이야기글 2 개, 설명글 2 개 총 4 개의 텍스트를 선정하였다. 읽기방식을 묵독과 음독으로 나누어 읽도록 하여 읽기유창성을 살펴보고, 읽기이해 평가문항에 답하도록 하였다. 질문 유형은 사실이해와 추론이해로 나 누고, 각 텍스트별 사실이해 4 문항, 추론이해 2 문항씩, 총 24 문항으로 구성하였다. 결과: 첫째, 학년이 증가함에 따라 읽기유창성 수행 력이 높아졌으며, 1 학년과 5 학년, 3 학년과 5 학년 집단에서 유의한 차이가 있었다. 읽기방식에 따라서는 음독보다 묵독에서 더 높은 수 행력을 보였다. 음독에서는 1 학년과 5 학년, 3 학년과 5 학년 집단에서 유의한 차이가 있었고, 묵독에서는 1 학년과 5 학년 집단에서 유의 한 차이가 나타났다. 둘째, 학년이 증가함에 따라 읽기이해 수행력이 높아졌으며, 1 학년과 3 학년, 1 학년과 5 학년 집단에서 유의한 차이 가 있었다. 읽기방식에 따라서는 묵독보다 음독에서 읽기이해력 점수가 더 높았으며 이러한 차이는 1 학년과 3 학년, 1 학년과 5 학년 집단 에서 유의하였다. 논의 및 결론: 본 연구 결과, 읽기유창성과 읽기이해 능력이 학년이 증가함에 따라 발달하며 묵독보다는 음독에서 읽 기이해 수행력이 높은 것으로 나타났다. 이러한 결과는 초등학교 저학년뿐만 아니라 고학년에서도 읽기이해 지도 시 음독에 대한 고려 가 필요하다는 점을 시사해주고 있다.

핵심어: 학령기 아동, 읽기유창성, 읽기이해, 음독, 묵독

본 논문은 제 1 저자의 석사학위논문을 수정·보완하였음.

\section{참고문헌}

권주석(2005). 생활 관련 읽기소재에 대한 사전경험이 읽기장애아동의 읽기유창성과 읽기이해력에 미치는 효과. 특수교육학연구, 40,313-331. 김광해(2003). 등급별 국어교육용 어휘. 서울: 박이정 김동일, 박춘성, 최종근, 김익수(2006). 초등학교 저학년 일반학급 및 특수학급 아동의 읽기 유창성 발달 특성. 교육심리연구, 20, 425-442. 김동일, 조영희, 고혜정(2015). 묵독유창성과 읽기이해와의 관계 탐색. 교육심리연구, 29, 169-183.

김민경, 강옥려(2010). 상보적 읽기전략 교수가 읽기부진아의 읽기유창성 및 읽기이해에 미치는 영향 학습장애연구, 7, 97-117.

김순복(2002). 이야기 구조를 통한 이야기 글 지도 방안 연구: 초등학교 3학년을 중심으로. 서울교육대학교 대학원 석사학위논문. 김애화, 김의정, 성소연(2013). 초등학교 1,3,5학년 학생의 읽기이해 특성 연구: 상위 읽기이해 처리 특성을 중심으로. 초등교육연구, 23, 21-42. 김애화, 박성희(2010). 초등학교 읽기장애 학생과 일반학생의 읽기유창성 특성 및 오류 유형 비교연구. 특수교육저널: 이론과 실천, 11, 323-344. 김애화, 박성희, 김주현(2010). 초등학생의 읽기유창성 특성 연구: 읽기 유창성 발달 패턴 및 오류 유형 분석. 언어청각장애연구, 15, 43-55. 김애화, 유현실, 김의정(2010). 단어인지, 읽기유창성, 읽기이해에 대한 예측 연구 5 세와 6세 아동을 대상으로 실시한 종단연구. 초등교육연구, 23, 427453.

김애화, 황민아(2008). 초등학교 고학년의 읽기능력에 영향을 미치는 읽기관련변인에 관한 연구 언어청각장애연구, 13, 1-25. 김영숙(2017). 읽기 \& 쓰기 교육. 서울: 학지사. 김영태, 홍경훈, 김경희, 장혜성, 이주연(2009). 수용·표현어휘력검사(REVT). 서울: 서울장애인종합복지관. 김혜리(2011). 읽기부진학생과 일반학생의 읽기유창성과 읽기이해능력 비교. 용인대학교 대학원 석사학위논문. 노은수(2010). 초등학교 수업에서 읽기방법이 내용파악에 미치는 효과. 공주교육대학교 대학원 석사학위논문. 
박승기(1969). 음독과 묵독이 읽기 능력에 미치는 영향에 관한 연구. 새국어교육, 13, 14-46.

박혜원(2014). 한국 비언어 지능검사 제2판(K-CTONI-2). 서울: 마인드프레스.

배소영, 김미배, 윤효진, 장승민(2015). 한국어 읽기검사(KOLRA). 서울: 학지사 심리검사연구소.

송영복(2009). 초등 다문화 학습자의 읽기유창성 신장 탐구. 한국초등국어교육, 41, 36-57.

왕문용(1981). 읽기 지도의 개선방안: 음독과 묵독문제. 한국국어교육연구회, 38, 185-196.

왕억문, 원미진(2017). 읽기 방법이 한국어 고급 학습자의 이해와산출에 미치는 영향: 음독과 묵독의 비교를 중심으로. 국제어문, 72, 205-228.

우정한, 신화성, 김종훈, 김민주(2016). 초등학교 읽기장애학생과 일반학생의 빠른 이름대기, 읽기유창성, 읽기이해 특성 및 관계비교. 특수교육재활 과학연구, 55, 163-183.

이일화, 김동일(2003). 읽기유창성과 독해력 수준과의 관계: 초등학교 저학년 학생을 중심으로. 교육심리연구, 17, 1-24.

장현숙(2016). 읽기방식에 따른 읽기이해 부진학생의 이야기 글 이해 능력. 단국대학교 대학원 석사학위논문.

정경희, 진연선, 곽경미, 김미배, 배소영(2017). 한국어 해독해 3 권 이야기와 설명 담화 독해. 서울: 학지사.

조미아(2007). 학년별 독서방식이 어린이의 자기주도적 학습능력에 미치는 영향에 관한 연구 한국문헌정보학회지, 41, 251-271.

황진애, 김영태, 이주연(2007). 학령기 아동의 읽기이해력 발달: 중심내용파악, 참조 및 추론능력을 중심으로. 언어청각장애연구, 12, 412-428. 